\title{
Modelling the Development of Rocky Shoreline Profiles along the Northern Coast of Ireland
}

\author{
Benjamin Thébaudeau ${ }^{1}$, Alan Trenhaile ${ }^{2}$ and Robin Edwards ${ }^{1}$ \\ ${ }^{1}$ School of Natural Sciences, Museum Building, Trinity College Dublin, Ireland. \\ ${ }^{2}$ Department of Earth Sciences, University of Windsor, Ontario, Canada. \\ Email: robin.edwards@tcd.ie
}

\begin{abstract}
A mathematical wave-erosion model is used to simulate postglacial shoreline profiles along the rocky, high energy coast of the north of Ireland. The wave erosion model is driven by a suite of relative sea-level (RSL) curves for the last 16,000 years produced from four glacial rebound models. Multiple runs are performed with different initial shore profiles and rock resistances to investigate shoreline evolution and the significance of inherited morphology on the resultant profile shape. The simulated profiles are then compared with mapped profiles from three areas of the north of Ireland with different lithological and hydrographic properties.

Modelled profiles generally replicate the overall mean shoreline gradients observed across the region when rock resistance is relatively high and erosion rates correspondingly low. In these profiles, breaks in mean slope are observed at depths comparable to the RSL minima in several of the RSL scenarios (at c. $-10 m,-15 m$ and $-20 m$ for North Antrim, Derry and Donegal respectively). At Portrush and Portballintrae (Derry), profiles may be influenced by structural controls relating to the underlying basalt surface and the removal of overlying glaciogenic sediments.

All RSL scenarios replicate the observed eastward increase in cliff-platform junction height, reflecting the differential glacioisostatic rebound experienced along the coast. However, the precise elevation at which the simulated cliff base occurs is sensitive to the choice of RSL scenario, suggesting that this parameter may prove useful in evaluating glacial rebound model performance. Several of the RSL scenarios generate raised shore platforms or terraces in North Antrim and Derry at heights comparable to raised shoreline features reported in the literature. However, no single curve or combination of parameters is capable of generating the range of platform and terrace features observed in the bathymetric and topographic data. These misfits are consistent with the idea that many rock platform or terrace features are inherited from an earlier phase or phases of RSL.
\end{abstract}

Keywords: wave erosion, model, relative sea level, rock coast, shore platforms, marine terraces, Ireland

Abbreviations: Relative Sea Level (RSL); Joint Irish Bathymetric Survey (JIBS); Digital Elevation Model (DEM); mean high water spring tide (MHWS), mean high water neap tide (MHWN), mid-tide (MT), mean low water neap tide (MLWN), and mean low water spring tide (MLWS); Ordnance Datum Malin Head (OD)

This is the author's final copy of a published manuscript made available via Trinity's Access to Research Archive (TARA).

This item is protected by original copyright.

For full details visit the TARA website at www.tara.tcd.ie

Citation: Thébaudeau, B., Trenhaile, A.S., Edwards, R.J. (2013) Modelling the development of rocky shoreline profiles along the northern coast of Ireland. Geomorphology 203, 66-78. http://dx.doi.org/10.1016/j.geomorph.2013.03.027 


\section{Introduction}

The high energy, wave dominated coastline of the north of Ireland comprises rocky cliffs and shore platforms, commonly associated with gravel ridges, beach sand and eolian dune deposits. In places, this rugged coastline is punctuated by more sheltered sea loughs (estuaries of glacial inheritance) and embayments which permit the accumulation of lowerenergy, finer grained estuarine sediment. Whilst rocky coasts are traditionally regarded as being less vulnerable to the effects of climate and sea-level change than their lower-energy sedimentary counterparts (e.g. Nicholls et al., 2007), their actual resilience is poorly quantified and a better understanding of long-term rocky coast evolution is required (Naylor et al., 2010). This issue has particular significance along the rocky coast of the north of Ireland, not least because of the presence of the Giant's Causeway World Heritage Site and associated concerns regarding climate-related increases in erosion and inundation (Orford et al., 2007).

In addition to its actively forming features, relict coastal landforms and facies are exposed along the northern coast of Ireland at a range of elevations above their contemporary counterparts (e.g. Praeger, 1897; Coffey and Praeger, 1904; Movius, 1953; Stephens, 1963, Prior, 1965; Orme, 1966; Synge and Stephens, 1966; Carter, 1982). This varied association of 'raised shorelines', which consists of erosional features such as rock platforms, notches, terraces and 'washing limits', and depositional features such as gravel ridges, or marine deltas, has been cited as evidence of higher than present relative sea-level (RSL) resulting from glacioisostatic rebound of this formerly glaciated region (Devoy, 1983, 1995; McCabe et al., 2007). Similarly, investigation of the inner shelf has identified potential beach deposits and erosional notches now submerged by several tens of metres of water, suggestive of periods during which RSL was below present (Cooper et al., 2002; Kelley et al., 2006).

However, despite more than a century of work, the RSL history of the north of Ireland remains poorly resolved and the subject of ongoing debate (Carter, 1982; Lambeck, 1995; Lambeck and Purcell, 2001; Peltier et al., 2002; Shennan et al., 2006; McCabe et al., 2007; Brooks et al., 2008; McCabe, 2008; Edwards et al., 2008). Difficulties in reliably delimiting the vertical relationships of inferred shorelines to the sea level at the time of their formation, coupled with uncertainties in constraining their age, have contributed to this lack of consensus. This situation is exemplified by the use of rocky shore morphology, such as shore platforms and notches, which have featured prominently in previous work.

Shore-platforms develop in the intertidal zone where erosional processes, such as hydraulic quarrying, operate at or near to the water surface (Trenhaile, 1997, 2000, 2012). Whilst they are clearly linked to RSL and tidal range, mean platform elevation and the height of the junction between the cliff and the seaward shore platform (the cliff-platform junction) varies within the intertidal zone according to wave exposure, weathering intensity and the resistance of the rock (Trenhaile and Byrne, 1986; Trenhaile, 2002). Consequently, these features can constrain the height of RSL but with vertical uncertainties of several metres (Carter, 1983).

With a change in RSL, shore platforms may be converted into subaerial or submarine terraces, or sloping erosional continental and island shelves. Since they can rarely be dated directly, these erosional features are usually interpreted in the light of associated sedimentary deposits and/or by correlation with other features of inferred equivalent age, although this reasoning sometimes becomes circular (Devoy, 1983). One particular challenge is distinguishing whether a rock platform is genetically linked to the most recent phase of RSL change, or is in fact inherited from an earlier RSL phase (or phases) (Young and Bryant, 1993; Brooke et al., 1994; Stone et al., 1996; Trenhaile et al., 1999; Trenhaile, 2002, 2010; Blanco Chao et al., 2003; McKenna, 2008).

Recent studies using a mathematical wave-erosion model have simulated the development of rock shore platforms and examined their morphology in relation to contrasting patterns of RSL change during the Holocene (Trenhaile, 2008, 2010). In this paper, we apply this modelling approach to simulate rocky shoreline development along the northern coast of Ireland. We drive the model using a range of postglacial RSL change scenarios and simulate the erosional effects on rocks of varying resistance. We then compare simulated and measured profiles to elucidate the formation of observed coastal features.

\section{Regional Setting}

The general study area encompasses the northern coast of Ireland extending from Lough Swilly (County Donegal) in the west, to Fair Head (County Antrim) in the east (Fig. 1). The region is wave-dominated under the influence of westerly to northerly winds throughout the year (Table 1 ). The tides are semidiurnal with a spring tidal range of around $3.5 \mathrm{~m}$ in the west of the region, decreasing to around $0.9 \mathrm{~m}$ in the east (Table 2). Analysis is focussed on three specific areas along this stretch of coast which are selected to provide a representative range of lithology, tidal range, aspect and morphology.

\begin{tabular}{ccc}
\hline $\mathbf{H}_{0}(\mathbf{m})$ & $\mathbf{F}(\%)$ & $\mathbf{T}(\mathbf{s})$ \\
\hline$<1$ & 5.6 & 5.1 \\
$1-2$ & 31.0 & 5.7 \\
$2-3$ & 28.2 & 6.7 \\
$3-5$ & 26.0 & 7.8 \\
$5-7$ & 7.1 & 9.2 \\
$7-9$ & 2.1 & 10.3 \\
\hline
\end{tabular}

Table 1: Summary wave data derived from the Irish Department of Transport buoy M4 (Station 62093), Donegal Bay (water depth = $72 \mathrm{~m}$ ). $\mathrm{HO}=$ binned significant wave height (metres); $\mathrm{F}=$ proportion of the total record in each bin; $T$ = average wave period within each 


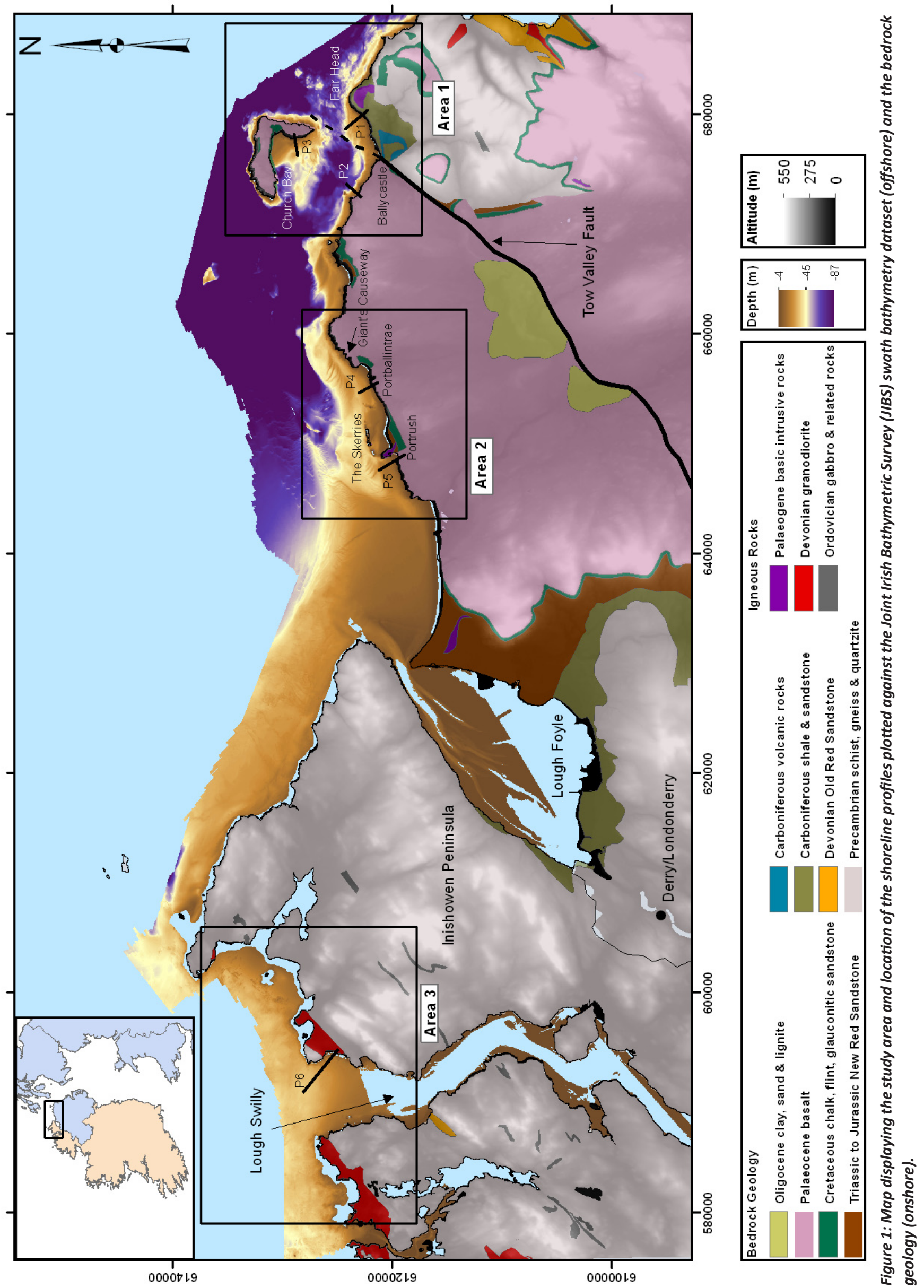




\begin{tabular}{ccccc}
\hline Tidal Station & \multicolumn{4}{c}{ Tidal Data (m OD Malin Head) } \\
& MHWST & MHWNT & MLWNT & MLWST \\
\hline Ballycastle & +0.5 & +0.2 & -0.1 & -0.4 \\
$\begin{array}{c}\text { (Area 1) } \\
\text { Portrush }\end{array}$ & & & & \\
$\begin{array}{c}\text { (Area 2) } \\
\text { Fanad Head }\end{array}$ & +0.7 & +0.6 & -0.3 & -0.8 \\
& +1.3 & +0.3 & -1.2 & -2.2 \\
(Area 3) & & & & \\
\hline
\end{tabular}

Table 2: Summary tidal data for the three study areas (m OD Malin Head). MHWST = Mean high water of spring tides; MHWNT = mean high water of neap tides; MLWNT = Mean low water of neap tides; MLWST = mean low water of spring tides.

Study area 1 (North Antrim) comprises Ballycastle Bay opening to the north, and Church Bay on Rathlin Island opening to the south west. The western half of Ballycastle Bay and the whole of Church Bay are etched into a Palaeocene basalt plateau that overlies Cretaceous chalk and greensand (Fig. 2). The eastern half of Ballycastle Bay is composed of Carboniferous limestone with a Tertiary dolerite sill, and it is separated from the western half by the Tow Valley fault which reaches the coast at the town of Ballycastle.

Study area 2 (Derry), comprising the north westerly facing coastline of Portrush and Portballintrae is situated to the west of study area 1 and adjacent to the Giant's Causeway World Heritage Site. In this area, the Palaeocene basalt plateau is close to modern sea-level with active shore platform development (Fig. 2). The Tertiary dolerite sill of Ramore Head and the Skerries divides the area in two and forms a sheltered 'inner sea' to the east of Portrush.

Study area 3 (Donegal) is situated at the mouth of Lough Swilly and presents a strong contrast to the other study areas in terms of its morphology and underlying geology. Here, the rocks are Precambrian quartzites and pelites, with a Devonian granodiorite pluton. The north westerly facing coastline lacks the prominent cliffs of North Antrim or Derry, and instead comprises exposed sloping rock surfaces that are mantled in places by sand or gravel beaches and windblown deposits.

The north of Ireland was completely ice covered at the last glacial maximum with ice extending onto the continental shelf (McCabe and Dunlop, 2006; Dunlop et al., 2010). Whilst deglaciation was distinctly non-monotonic, with retreat proceeding at variable rates and being interrupted by phases of ice re-advance, the coast as a whole is thought to have been predominantly ice

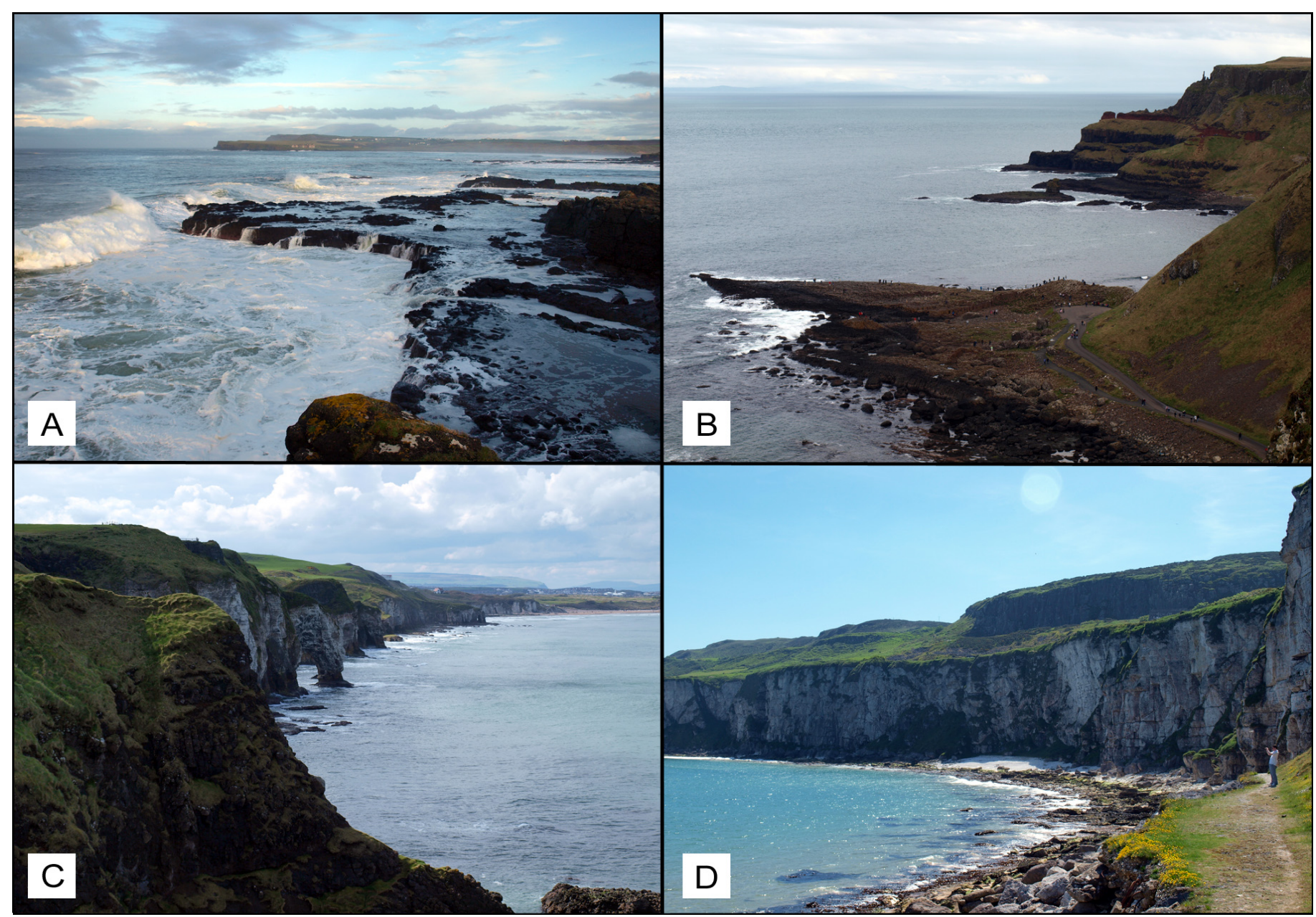

Figure 2: A) Modern sub-horizontal shore platform forming in Palaeogene basalt, Seaport lodge, Portrush (Area 2); B) Shore-platform at the Giant's Causeway, forming in columnar Basalt. C) Modern Cretaceous chalk cliffs with an actively eroding arch, capped by Palaeogene basalt, White rocks west of Portballintrae (Area 2). D) Modern Cretaceous chalk cliffs with gently sloping shore platform backed by a beach and capped by Palaeogene basalt, Larry Bane bay in the western half of Ballycastle bay (Area 1). 
free by around 16,000 BP (see Clark et al., 2012 for a recent review). The RSL history of the region is strongly controlled by the combined effects of local ice loading and the influence of adjacent ice masses over Britain and Fennoscandinavia. The resulting complex interplay between glacioisostatic rebound and eustatic sea-level rise is expressed as an oscillating postglacial RSL curve that comprises intervals with sea levels both above and below present. Whilst the details of the timing, magnitude and rates of these changes are subject to debate, the non-monotonic nature of postglacial RSL change in the region is a common feature across sea-level curves, irrespective of whether they are derived from glacial rebound modelling or the interpretation of field data (e.g. McCabe et al., 2007; Brooks et al., 2008).

\section{Material and Methods}

\subsection{Geomorphological Mapping}

Geomorphological analysis was conducted on a composite dataset comprising an onshore topographic component collected by LIDAR (Ordnance Survey of Ireland; Ordnance Survey of Northern Ireland) and an offshore bathymetric component collected by high resolution bathymetric and backscatter mulitbeam survey under the auspices of the Joint Irish Bathymetric Survey (JIBS) (see http://www.marine.ie/ home/services/surveys/seabed/JIBS.htm). The topographic data take the form of a digital elevation model (DEM) with a $10 \mathrm{~m}$ lateral resolution and a $0.5 \mathrm{~m}$ vertical resolution. The JIBS data were processed using IVS Dmagic 7 software (standard bandpass filter and krigging interpolation) to create DEMs at $1 \mathrm{~m}$ and $6 \mathrm{~m}$ lateral resolutions and the same vertical resolution (c. $0.5 \mathrm{~m}$ ). The $1 \mathrm{~m}$ DEM was used for the identification of individual seafloor features, whilst the $6 \mathrm{~m}$ DEM was used in the presentation of the coastal profiles (Fig. 3). Both DEMs were plotted together using IVS Fledermaus 7.

The bathymetric data were systematically analysed, recording breaks of slope to delimit regions of seafloor that were then cross-referenced with backscatter data to establish the nature of the substrate. Where a rock terrace feature was identified, its dimensions, depth, and gradient were recorded, along with the morphology of the delimiting breaks of slope above and below it, the lithology of the rock and the thickness of any modern sediments associated with it. Identification of lithology was only problematic where Paleocene basalt overlies Cretaceous chalk at varying elevations along the coast. In these instances, lithology was identified with reference to borehole data (McCann, 1988) and direct observation by diver (Quinn et al., 2010). The environmental conditions of exposure to modern wave action and local tidal range were also recorded and the entire dataset was compiled in a spatial database using the ArcGIS 9 software. These data were then synthesised to produce six morphological profiles that capture the dominant topographic features of each of the study areas (see Section 4.1; Fig. 3).

\subsection{Wave Erosion Modelling}

Wave erosion on hard rock coasts is accomplished mainly by the dislodgement and removal of joint blocks and other rock fragments, usually by broken waves (Trenhaile, 1987; Swantesson et al., 2006; Trenhaile and Kanyaya, 2007; Stephenson and Naylor, 2011).The processes responsible for wave quarrying, such as water hammer (impact) and the waveinduced compression of pockets of air in rock crevices, operate at or close to the water surface, which migrates up and down the foreshore with the tides and with changes in RSL. The evolution and profile development of a rock coast through mechanical wave erosion therefore reflects the amount of erosion accomplished at each elevation according to the resistance of the rock, the wave regime, the effect of submarine topography on rates of wave attenuation, and the amount of time that the waves have operated at each level (Trenhaile, 2000).

We simulate these processes using a wave erosion model that was developed for rocky coasts and has been used to elucidate their morphological evolution at various locations around the world (see Trenhaile, 2000; 2010). The model, which employs basic wave equations to determine rates of profile backwearing (erosion in the horizontal plane) at the water surface, has been described in detail elsewhere (Trenhaile, 2000, 2001).

In brief, the mechanical wave erosion by direct wave impact is represented by an excess surf stress expression:

$$
E_{b f}=N_{o} K_{b f}\left(S F-S F_{c r}\right)
$$

where: $E_{b f}$ is the recession ( $m \mathrm{yr}^{-1}$ ) accomplished by a single wave type at a single intertidal elevation each year; $N_{0}$ is the number of waves of that type at that intertidal level each year (based on wave period, frequency and tidal duration, the latter being the annual total number of hours the tide occupies a given elevation); $\mathrm{K}_{\mathrm{bf}}$ is a wave erosion calibration coefficient that converts excess surf stress to the rate of cliff or platform recession; SF is the stress $(\mathrm{Pa})$ exerted by the surf at the bluff foot, and $\mathrm{SF}_{\mathrm{cr}}$ is the threshold (critical) surf stress $(\mathrm{Pa})$, required to initiate erosion by wave impact.

The surf stress (SF) was calculated in the model using:

$$
S F=\left[0.5 \gamma\left(H_{b} / 0.78\right) e^{-x . S w}\right]
$$

where: $\gamma$ is the specific weight of water (about $1025 \mathrm{~kg} \mathrm{~m}^{-}$ ${ }^{3}$ for seawater); $H_{b}$ is the mean breaker wave height $(m), \chi$ is a dimensionless surf attenuation constant representing the roughness of the bottom; and Sw is the width of the surf zone. As in previous studies, a value of $\chi=0.01$ was used to represent surf attenuation over fairly even bottoms (see Trenhaile, 2000, 2001).

A decay function is used to represent slow rates of submarine erosion $\left(E_{u}\right)$ :

$$
E_{u}=E_{y} e^{s h}
$$

Where: $E_{y}$ is the erosion at the waterline; $s\left(\mathrm{~m}^{-1}\right)$ is a depth decay constant (set to 1 in the runs performed here); and $h$ is the water depth (m). 

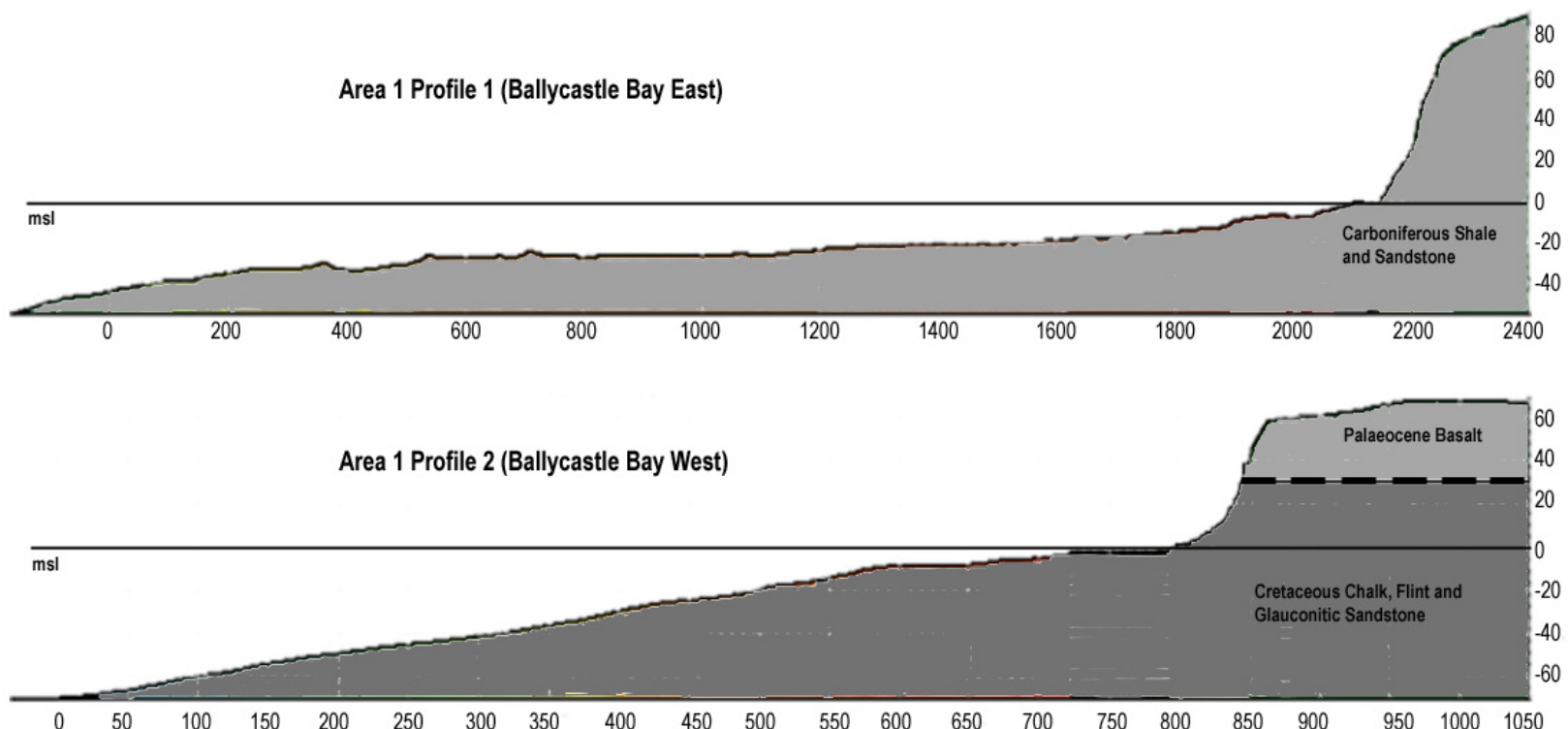

Area 1 Profile 3 (Church Bay, Rathlin Island)
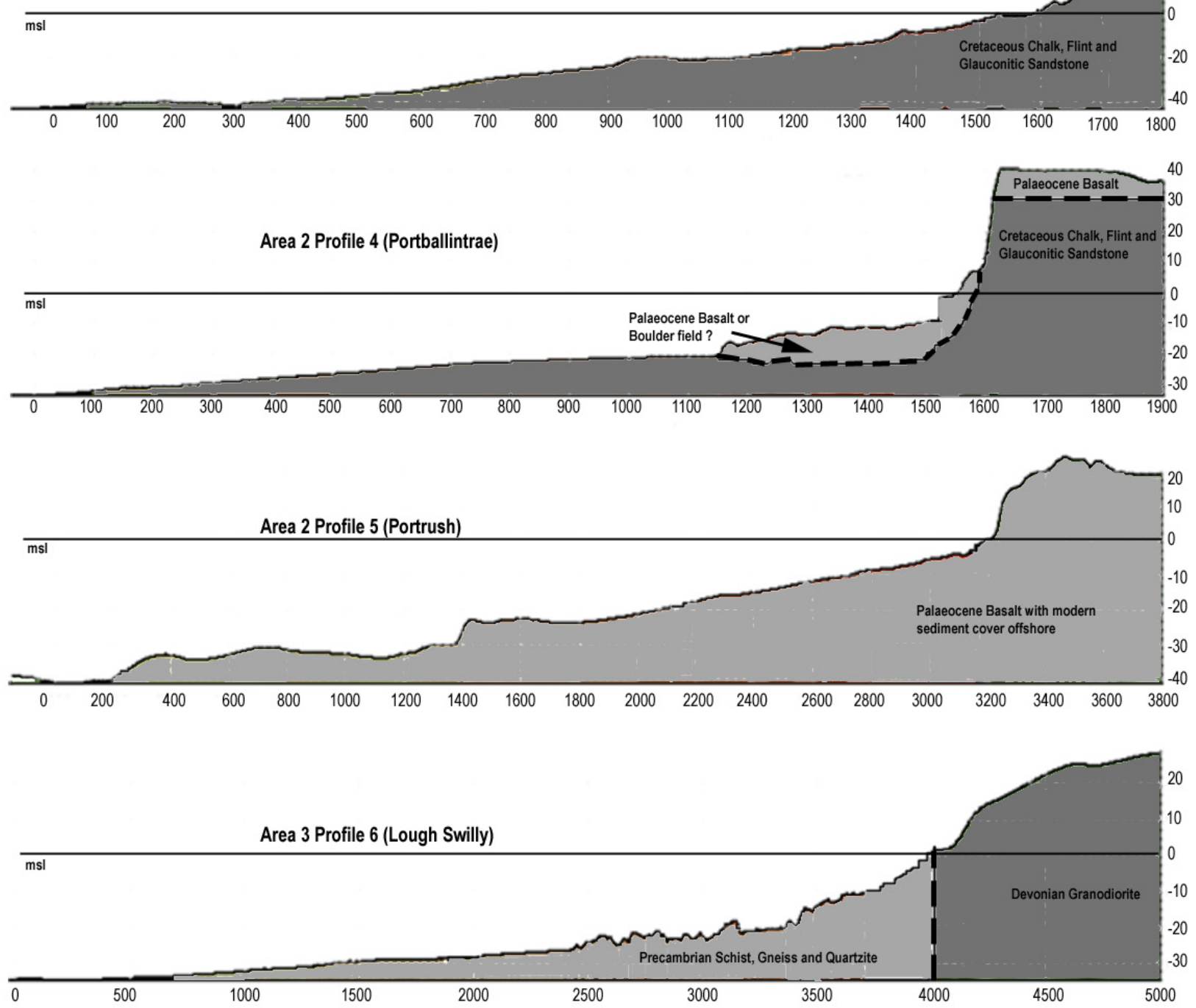

Figure 3: Composite coastal profiles derived from high resolution swath bathymetric data. Major changes in lithology are indicated schematically on each profile for reference. MSL = mean sea level. 


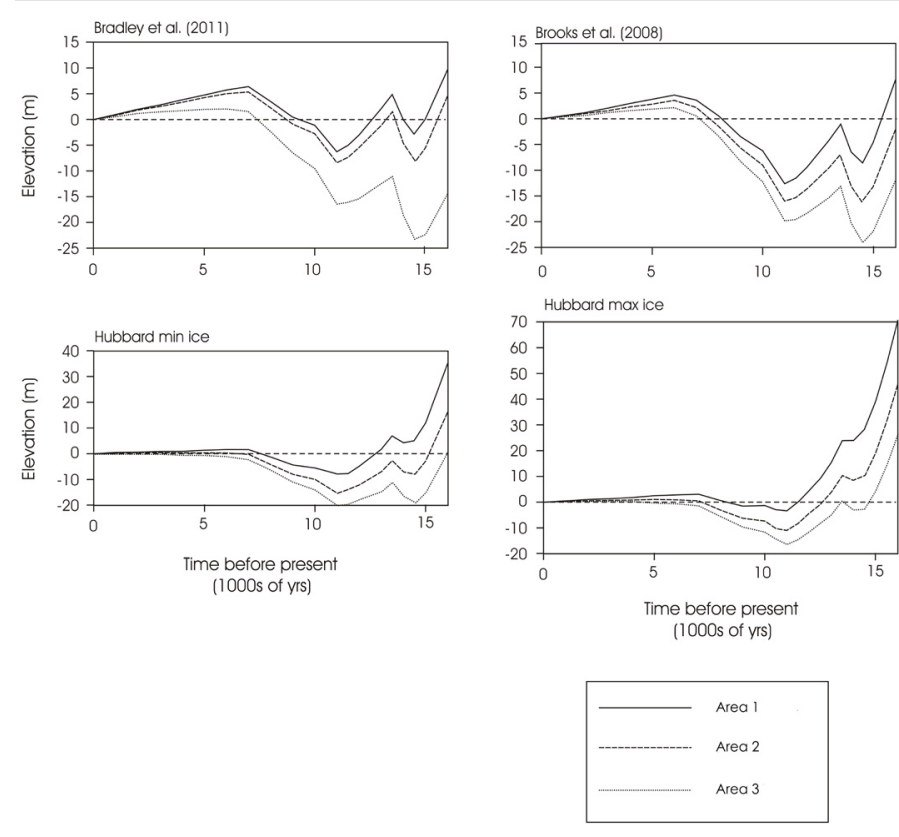

Figure 4: Simulated relative sea level (RSL) curves for the 3 study areas generated by the glacial rebound models of Bradley (Bradley et al., 2011); Brooks (Brooks et al., 2008); Hub-min and Hub-Max (Kuchar et al., 2012)

The model is driven using modern average wave climate and tidal regime (data from the Marine Institute: www.marine.ie; and the British Oceanographic Data Centre: www.bodc.ac.uk), with the tidal duration distribution for a given height calculated as outlined in Smart and Hale (1987). Model runs commence at 16,000 BP broadly equating to the time when the coast was first generally free of ice. In the absence of precise local RSL data for this period (Carter, 1982; Brooks and Edwards, 2006), we employ a range of RSL scenarios derived from glacial rebound modelling (Fig. 4). Whilst all the RSL curves show similar overall patterns, including differential east-west isostatic rebound, and an inflection at $14,000 \mathrm{BP}$ related to Meltwater pulse $1 \mathrm{a}$, they differ in the rate of RSL change as well as the duration and magnitude of RSL high or lowstands. Full details of the glacial rebound models and their development are available in Brooks et al. (2008) (hereafter the 'Brooks model'), Bradley et al. (2011) (hereafter the 'Bradley model'), and Kuchar et al. (2012) (hereafter the 'Hub-Min' and 'Hub-Max' models). Threshold rock resistance values $\left(\mathrm{SF}_{\mathrm{cr}}\right)$ are varied between 100 to 1100 to simulate contrasting 'hard' and 'soft' lithologies following Trenhaile (2000, 2001). Whilst other wave, tide or RSL scenarios are possible, the values used here are sufficient to provide a first order assessment of shore-profile development in the region.

The amount of erosion accomplished by wave quarrying in the intertidal zone is calculated from Equation (1) at the end of each 5-year iteration. Calculations are made at five elevations representing mean high water spring (MHWS), mean high water neap (MHWN), mid-tide (MT), mean low water neap (MLWN), and mean low water spring (MLWS) tidal levels. The amount of submarine erosion is determined using Equation (3) at 0.5 $\mathrm{m}$ vertical intervals extending from the MHWN tidal level to a depth equal to half the wavelength of the waves.
Initial model runs are made on virgin, linear slopes, generally with gradients of $2.5^{\circ}, 5^{\circ}$ or $35^{\circ}$. To examine the effect of inheritance, additional runs are made on profiles that initially comprise two linear slope elements: a gently sloping surface below the modern low tidal level (MLWS) with a gradient of either $2.5^{\circ}$ or $5^{\circ}$, and a steep surface with a gradient generally of $35^{\circ}$ to represent a degraded former cliff above the low tidal level.

The effect of individual factors, such as the slope and shape of the initial surface, the resistance of the rock $\left(\mathrm{SF}_{\mathrm{cr}}\right)$, and the RSL curve is determined by comparing profiles produced by replicate model runs in which all variables bar the one of interest are held constant.

\section{Results}

\subsection{Bathymetric mapping and submerged shore platforms}

More than 500 sub-horizontal platform or shallow sloping terrace features were identified across the survey area, at a range of depths and incised into a variety of bedrock lithologies, including Palaeocene basalt, Cretaceous greensand and chalk, Carboniferous limestone and Precambrian metamorphic rocks. In general, seafloor roughness is greatest between depths of 3 to $15 \mathrm{~m}$. The maximum concentration of subhorizontal platforms (with a slope of less than $0.8^{\circ}$ ) generally occurs at greater depth in areas 1 and 3 , than in area 2.

Six composite shoreline profiles compiled from the bathymetric mapping and topographic DEM are presented in Figure 3. In area 1 , three profiles are constructed representing the contrasting lithologies within Ballcastle Bay (Profiles 1, 2), and the more sheltered environments within Church Bay on Rathlin Island (Profile 3). Profile 1, representing the eastern half of Ballycastle Bay, comprises three main elements: the sill in the cliff face of Fair Head which extends from the intertidal zone to an elevation of $80 \mathrm{~m}$ without any marked breaks of slope; a sloping $\left(\sim 2^{\circ}\right)$ terrace about $250 \mathrm{~m}$ wide extending from the intertidal area to a depth of approximately $-8 \mathrm{~m}$; and a second sloping terrace $\left(\sim 1^{\circ}\right)$ about $1000 \mathrm{~m}$ in width and extending from $-15 \mathrm{~m}$ to -30 $m$ depth, that is backed by a small submerged cliff face (Fig. 3, profile 1). Both submerged terraces are carved in Carboniferous limestone whilst the cliff face is formed by the basalt plateau.

In the western portion of Ballycastle Bay (Profile 2) the cliff section is similar to that of Profile 1 , but there are consistent differences in the submerged terrace profiles which are cut into Cretaceous chalk and greensand. Here, a sloping $\left(\sim 3^{\circ}\right)$ terrace surface between 20 and $200 \mathrm{~m}$ wide extends from the intertidal zone to a depth of $-7 \mathrm{~m}$. This gives way to a subhorizontal platform between 15 and $70 \mathrm{~m}$ wide. A second subhorizontal platform up to $150 \mathrm{~m}$ in width is intermittently recorded at a depth of around $-17 \mathrm{~m}$, below which the gradient of the seafloor increases to $1.8^{\circ}$. In Church Bay (Profile 3 ), the same general morphology is observed except that the sub-horizontal platform at $-7 \mathrm{~m}$ is absent. Instead, the upper sloping terrace surface terminates in an abrupt cliff face at $-10 \mathrm{~m}$. 
In study area 2, there are Cretaceous chalk cliffs up to $45 \mathrm{~m}$ in height to the west of Portballintrae, rising from a $20 \mathrm{~m}$ wide sub-horizontal platform at around $+6 \mathrm{~m}$ (Fig. 3, profile 4). Sand dunes cover Jurassic sedimentary rocks up to the town of Portrush (Fig. 3, profile 5), where the Tertiary dolerite sill of Ramore Head and the Skerries protrudes from the modern coast. West of Portrush, cliffs of Palaeocene basalt extend from the intertidal zone to around 20 to $25 \mathrm{~m}$ in height. Whilst there are no bathymetric data between the intertidal zone and -10 $\mathrm{m}$ along the chalk coast, a sloping terrace $\left(\sim 2^{\circ}\right)$ is present from the intertidal zone to a depth of $-15 \mathrm{~m}$ on the basalt coast to the west of Portrush. There is a sloping terrace $\left(\sim 1.3^{\circ}\right)$, about $300 \mathrm{~m}$ wide, from $-10 \mathrm{~m}$ to $-16 \mathrm{~m}$ in the chalk (Fig. 3, profile 4), and a subhorizontal platform, up to $1000 \mathrm{~m}$ wide, from $-15 \mathrm{~m}$ to $-20 \mathrm{~m}$ in the basalt (Fig. 3, profile 5). Around the Skerries, a subhorizontal platform forms a flat seabed at a depth of $-20 \mathrm{~m}$.

In the study area 3 (Fig. 3, profile 6), there is a wide (150 m), gently sloping $\left(\sim 3^{\circ}\right)$ terrace extending from the intertidal zone to a depth of $-20 \mathrm{~m}$. This is succeeded by a sub-horizontal platform with an uneven surface up to $1000 \mathrm{~m}$ wide, which terminates in a short drop to the Malin shelf.

slow erosion

Area 1 :
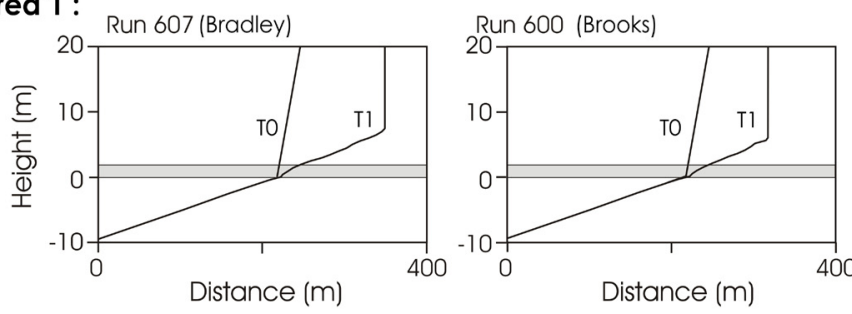

Area 2:
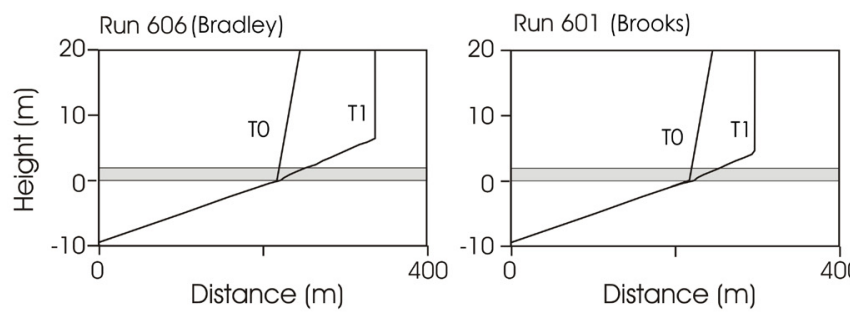

Area 3:
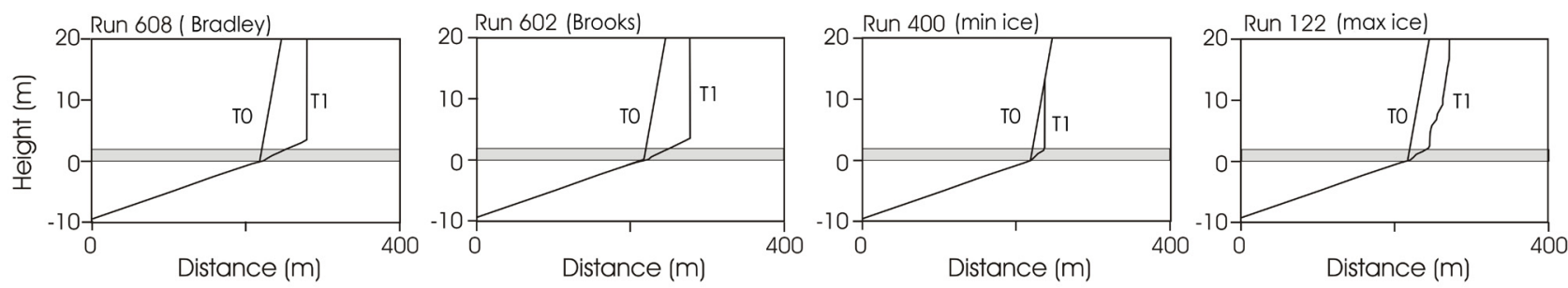
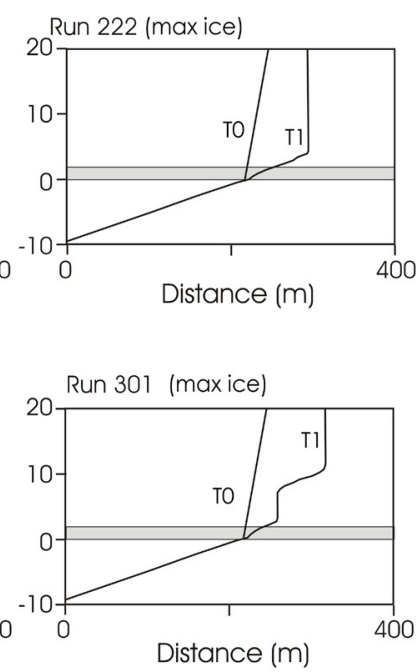

Distance $(m)$

Figure 5: Slow Erosion (SFcr=1000): Modelled shoreline profiles showing the modification by waves of a slowly eroding coastline with inherited morphology for each of the three study areas and four relative sea-level scenarios. The initial profile (TO) comprised a linear surface with a $5^{\circ}$ slope below mean low water spring tides (MLWS) and a steeper surface of $35^{\circ}$ above MLWS. T1 = the resulting profile. The modern tidal range is plotted as a shaded area. 
fast erosion

Area 1 :
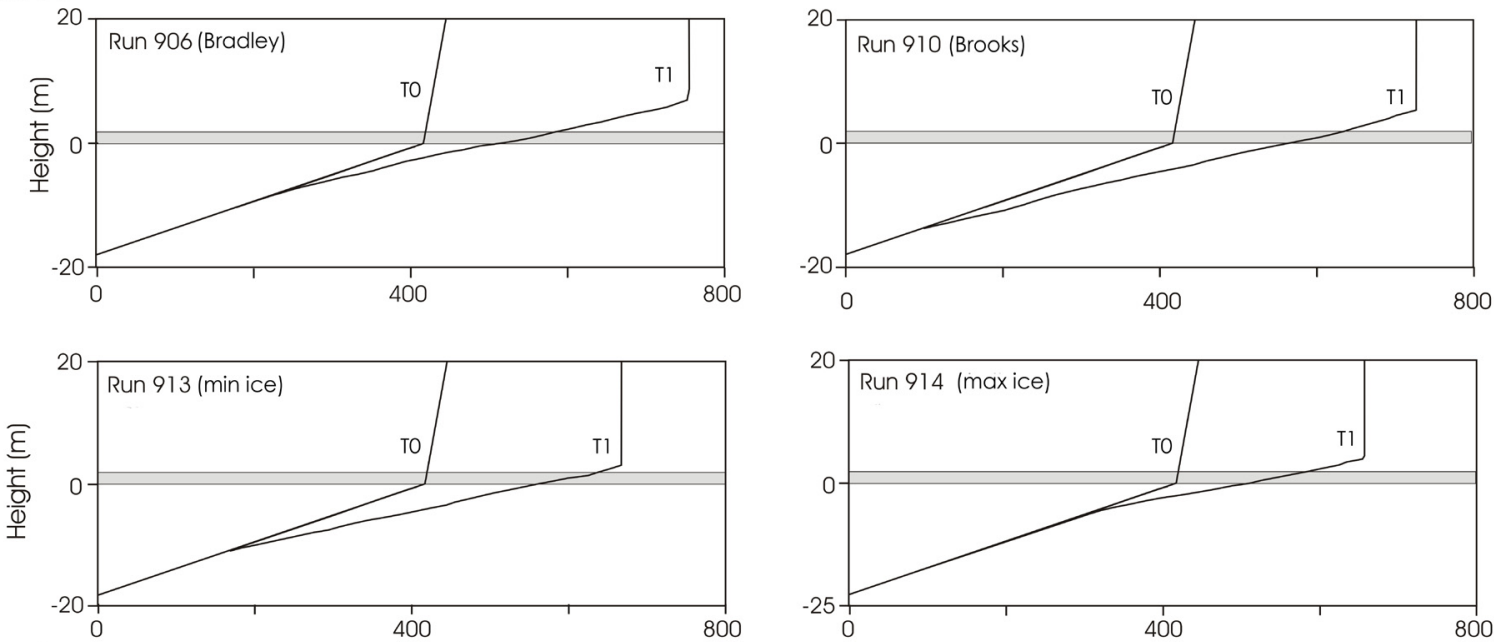

Area 2 :
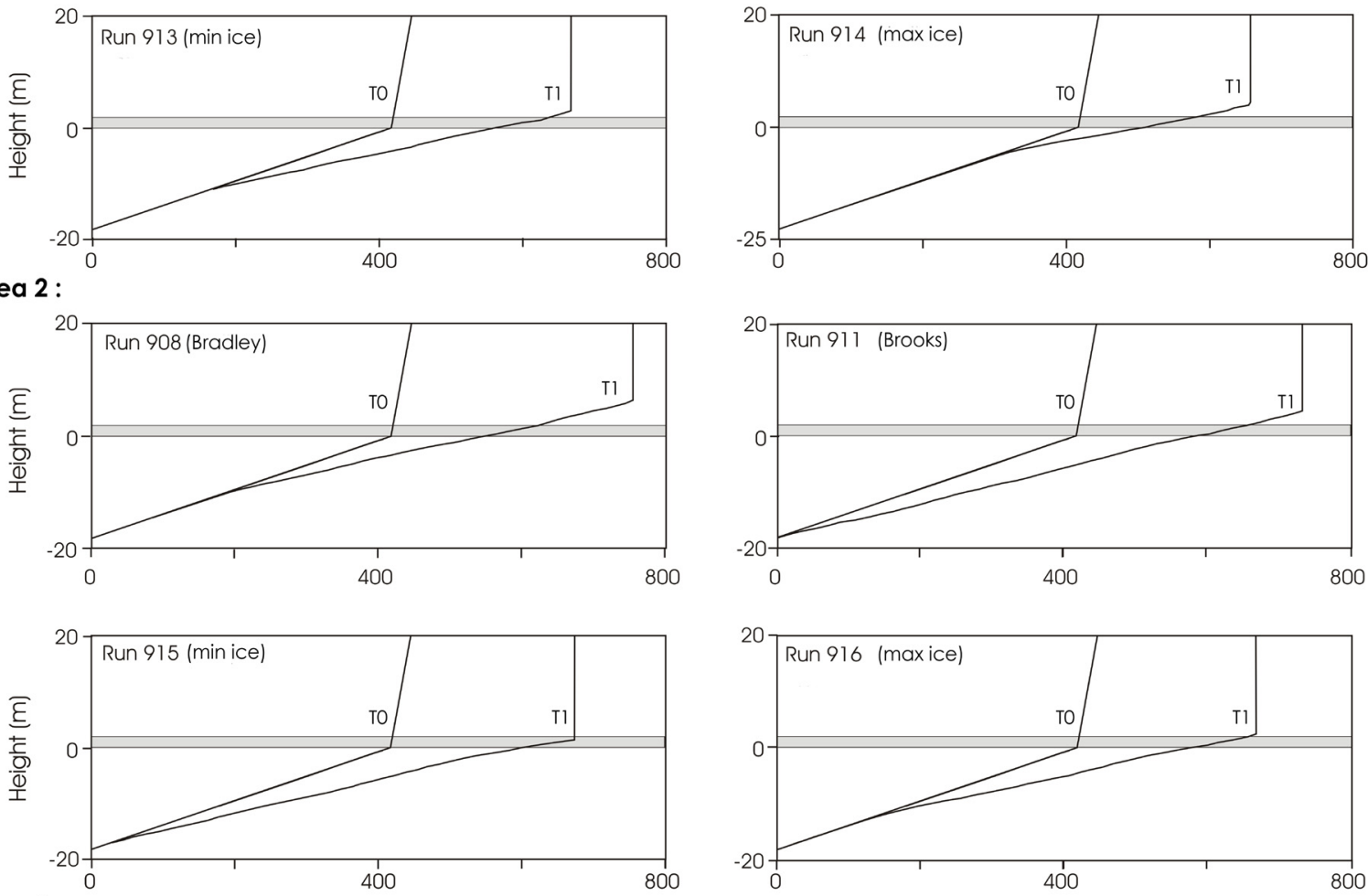

Area 3:
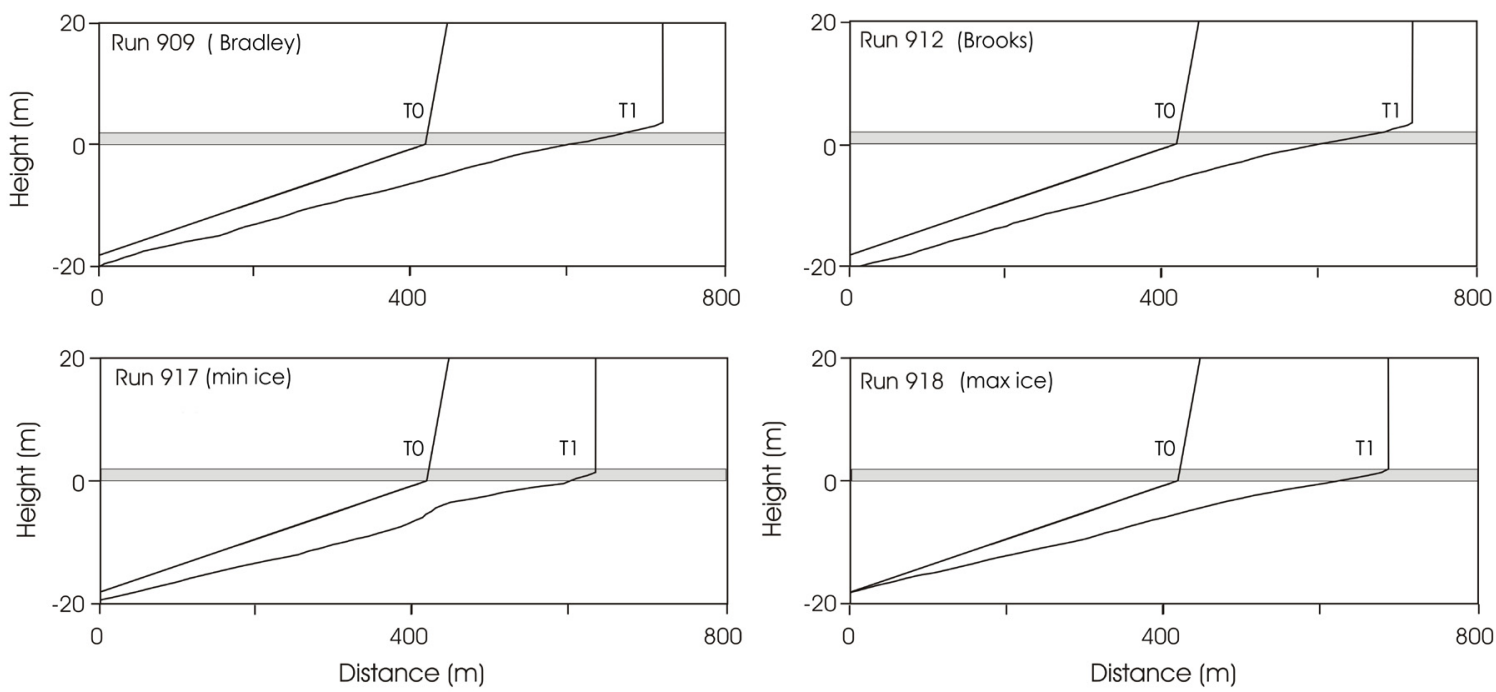

Modern tidal range

Figure 6: Fast Erosion (SFcr= 500): Modelled shoreline profiles showing the modification by waves of a rapidly eroding coastline with inherited morphology for each of the three study areas and four relative sea-level scenarios. The initial profile (TO) comprised a linear surface with a $5^{\circ}$ slope below mean low water spring tides (MLWS) and a steeper surface of $35^{\circ}$ above MLWS. T1 = the resulting profile. The modern tidal range is plotted as a shaded area. 


\begin{tabular}{|c|c|c|c|c|c|c|}
\hline Area & $\begin{array}{l}\text { Cliff-Platform } \\
\text { Junction }\end{array}$ & Bradley & Brooks & Hub-Min & Hub-Max & Measured \\
\hline \multirow[t]{3}{*}{ (1) N. Antrim } & Mean & 6.6 & 3.9 & 2.6 & 4.1 & \multirow{3}{*}{$1.8-2.3$} \\
\hline & Max & 7.1 & 4.1 & 3.6 & 4.6 & \\
\hline & Min & 6.1 & 3.6 & 1.6 & 3.6 & \\
\hline \multirow[t]{3}{*}{ (2) Derry } & Mean & 5.7 & 3.4 & 1.4 & 1.7 & \multirow{3}{*}{$0.2-2.2$} \\
\hline & Max & 6.2 & 3.7 & 1.7 & 2.2 & \\
\hline & Min & 5.2 & 3.2 & 1.2 & 1.2 & \\
\hline \multirow[t]{3}{*}{ (3) Donegal } & Mean & 1.3 & 1.1 & -0.4 & -0.2 & \multirow{3}{*}{$-1.3--0.2$} \\
\hline & Max & 2.3 & 1.3 & -0.2 & 0.3 & \\
\hline & Min & 0.8 & 0.8 & -0.7 & -0.7 & \\
\hline
\end{tabular}

Table 3: Simulated altitude of the cliff-platform junction ( $m$ OD Malin Head) for each study area and relative sea-level scenario (see text for details), compared with the observed altitude from the topographic data.

Cliff-platform junction height decreases to the west and is generally between 0.25 to $0.5 \mathrm{~m}$ lower in runs using less resistant rock. With the exception of runs driven by the Hub-min model RSL curve, which produces cliff-platform junctions in the upper portion of the modern intertidal zone, cliff bases are usually produced that are up to several metres above the present high tidal level in all three areas (Table 3). The formation of subhorizontal shore platforms and terraces is strongly associated with the slowest rates of RSL change (see Section 5).

To explore these general features in more detail, we consider the evolution of the subtidal, intertidal and supratidal components of profiles from each study area, produced by multiple runs employing different RSL scenarios for both high and low resistance rock (Figs. 5, 6).

\subsubsection{The subtidal zone}

In all runs, erosion of the submarine shelf tends to produce surfaces extending down to depths of about $5-7 \mathrm{~m}$ that are slightly convex upwards, with mean gradients which increase with rock resistance and range from about $1.5^{\circ}$ to $3.5^{\circ}$. No steplike submarine terraces backed by very steep scarps are formed, but one or more subtle increases in gradient (typically of less than $2^{\circ}$ extending over elevations of only a few metres) do occur in a number of runs. These changes are generally within depths of less than $15 \mathrm{~m}$ of the present low tidal level, and in runs with moderately resistant rock (Fig. 7, Area 1 and Area 2). Erosion at the lowest postglacial RSL in Area 3 also produces some terraces at depths ranging from about - 23 to $-15 \mathrm{~m}$ (Fig. 7, Area 3). Some more prominent terraces with gently sloping surfaces (gradients $1-2^{\circ}$ ) backed by slopes of as much as 10 to $15^{\circ}$ (Fig. 6, run 917) generally develop in runs with resistant rocks $\left(\mathrm{SF}_{\mathrm{cr}}>=700\right)$. These are found at around $-6 \mathrm{~m}$ in Area 2, and at about $-20 \mathrm{~m}$ and $-14 \mathrm{~m}$ in Area 3 when using the Bradley model RSL curve. Terrace formation is less frequent in the three study areas when employing the Brooks and Hub-Min model RSL curves (Figs. 5, 6).

\subsubsection{The intertidal zone}

In most runs, the modern shore platforms, extending from the MLWS to the MHWS tidal levels, range from about 50 to
$150 \mathrm{~m}$ in width, with corresponding mean gradients of $2.3^{\circ}$ to $0.75^{\circ}$. The widest platforms and terraces with the lowest slope gradient develop in the least resistant rocks. The platforms are generally broadly linear, although some are gently concave or convex in shape. Varying the RSL curve elicits an array of contrasting responses, although in general platforms produced during runs driven by the Hub-Min and Hub-Max RSL models are, respectively, about 10 to $15 \mathrm{~m}$ narrower and wider than those produced by the Brooks and Bradley RSL curves.
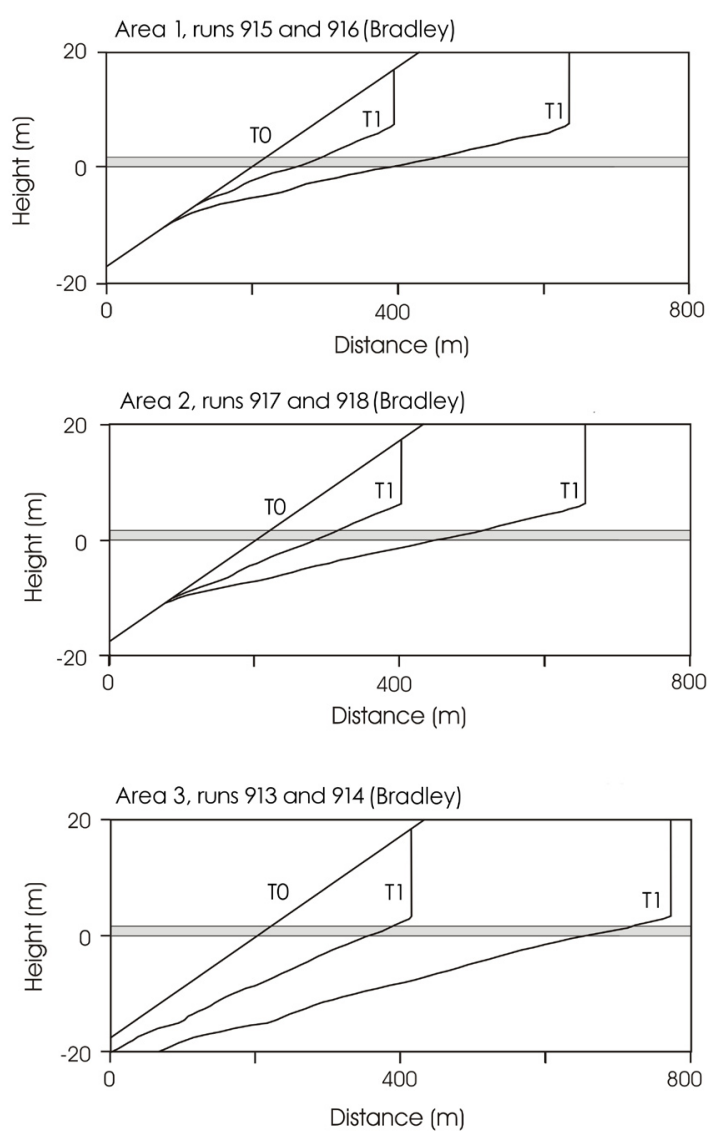

Figure 7: Modelled shoreline profiles for each study area illustrating the formation of sub-tidal terraces and breaks in slope in an initially linear surface under moderate erosion (500 < SFcr < 1000) when driven by relative sea-level curves produced by the Bradley glacial rebound model (Bradley et al., 2011). 


\subsubsection{The supratidal zone}

Erosion above the modern low tidal level generally produces a single vertical cliff, both in runs that commence with a single linear, sloping surface, and those with an inherited cliff in the initial profile. As noted previously, the absence of erosion in runs with a very low initial gradient and resistant rocks means that the supratidal zone consists entirely of the initial surface. In most runs, however, erosion creates a cliff that extends up to a point above the highest RSL represented in each of the curves, where the initial surface is unmodified. In a few runs for area 1, using the Hub-Min and Hub-Max RSL curves and resistant rocks, the top of the cliff is lower than the highest RSL and the surface above the cliff top is modified by wave erosion to produce irregular slopes with elements that are both steeper and gentler than the initial slope (e.g. Fig. 5, Run 223). In a few runs with cliffed initial profiles and resistant rocks $\left(\mathrm{SF}_{c r}>=750\right)$, profiles comprising two vertical cliffs separated by a gently sloping terrace are generated when driven by the Hub-Min and HubMax RSL curves. Most of these subaerial terraces occur in runs for area 1 and range from 1 to $27 \mathrm{~m}$ in width and, depending on their width and gradient, are about 5 and $8 \mathrm{~m}$ above the modern high tidal level (MHWS)(Fig. 5, run 223). Other, well defined, gently sloping subaerial terraces several tens of metres in width are produced less frequently in runs for area 2 (Fig. 5, run 301), where they develop between 7.5 and $11.5 \mathrm{~m}$ above the present high tidal level (MHWS).

\section{Discussion}

The simulated profiles provide a first order assessment of the wave erosion experienced along the north of Ireland coast since it became permanently ice free around 16,000 years ago. By holding wave and tidal regime constant, the influence of differences in rock resistance, profile gradient and RSL history can be examined. As rock resistance increases, the mean profile steepens and becomes narrower. However, profile shape is also controlled by wave efficacy and the duration of erosion at a given height. Consequently, changes in shoreline slope in space and through time, coupled with the shape of the RSL curve will modify this general relationship.

\subsection{Mean profile gradients}

Comparison of modelled and mapped shoreline profiles from each area permits some general conclusions to be drawn. The overall mean gradient is most meaningfully compared across the intertidal to subtidal portions of the profiles extending down to around $15 \mathrm{~m}$ water depth (Fig. 8). As RSL only briefly occupies heights below this range, significant modification of the initial profile can only be accomplished with extremely rapid rates of erosion which, in turn, result in poor fits between modelled and mapped profiles across the remainder of the height range. Best overall fits are predominantly found in runs with moderate to slow rates of erosion $\left(\mathrm{SF}_{\mathrm{cr}}=500\right.$ to 1150). Generally good agreement in mean gradient is observed for Profile 1 (limestones, shale and sandstone) and Profile 3 (chalk) in Area 1, and Profile 6 (quartzites and pelites) in Area 3. It is noteworthy that the breaks in slope at c. $-10 m,-15 m$ and $-20 m$ for the measured Profiles 1, 3, and 6 respectively, correspond to the RSL minima for each of these areas as simulated by the Brooks and Hub-min models. This is consistent with the idea of only minimal modification of the seafloor below c. $20 \mathrm{~m}$ by RSL change during the last 16,000 years.

Reasonable fits are also obtained in Area 2 for Profile 4 (chalk) at Portballintrae and, to a lesser extent, the slightly concave up Profile 5 (basalt) at Portrush. The backscatter and bathymetric data reveal a highly irregular, sloping surface from about -10 to $-20 \mathrm{~m}$ in Profile 4. Whilst groundtruthing will be required to establish its composition, it could represent outcropping basalt below the chalk, or a boulder field, perhaps associated with the submerged glaciogenic sediments reported from the region (e.g. Kelley et al., 2006; Dunlop et al., 2010). In any event, the different lithology and surface roughness of this feature in comparison to other parts of the profile which are incised into chalk, may account for some of the mismatch between modelled and measured profiles at this location. For example, McKenna et al. (1992) highlight the role of basalt flow structure and weathering horizons in promoting irregular, stepped shoreline profiles along the Causeway coast.

In contrast to the other sites, at Portrush the closest agreement between modelled and measured profiles is obtained with a comparatively low critical surf stress value $\left(\mathrm{SF}_{\mathrm{cr}}=240\right)$ corresponding to much more rapid erosion. The measured profile is also influenced by a covering of modern surficial sediments. One possible explanation for the required low resistance in this area would be incision into glacial diamict rather than underlying basalt. Kelley et al. (2006) report glacial sediments and gravel deposits beneath a cover of Holocene sand in the Portrush area.

Despite good agreement between modelled and measured profiles in the eastern portion of Ballycastle Bay, the wide sub-horizontal platform at -7 to $-8 \mathrm{~m}$ in the western part of Ballycastle Bay could not be simulated satisfactorily. In some runs, a slight reduction in slope gradient is observed at these depths corresponding to brief still-stands in the Brooks and Bradley RSL curves. The available data provide no indication that this feature is lithologically or structurally controlled. Whilst the underlying geology is similar to that of the adjacent profile in Church Bay (Profile 3), the aspect of the two stretches of coastline is contrasting, with the western portion of Ballycastle Bay being more sheltered from wave action. Whilst a reduction in wave energy cannot account for enhanced formation of a shore platform, it is consistent with the increased preservation potential of an older featured inherited from a previous phase or phases of lower than present RSL.

\subsection{Platform features, cliff-platform junction height and relative sea-level}

The possibility that many shore platform features in the study area are metachronous or inherited is widely acknowledged in the literature (e.g. Orme, 1966; Carter, 1982; McKenna, 2002, 2008), although difficulties in developing reliable chronologies have commonly frustrated attempts to distil more precise 

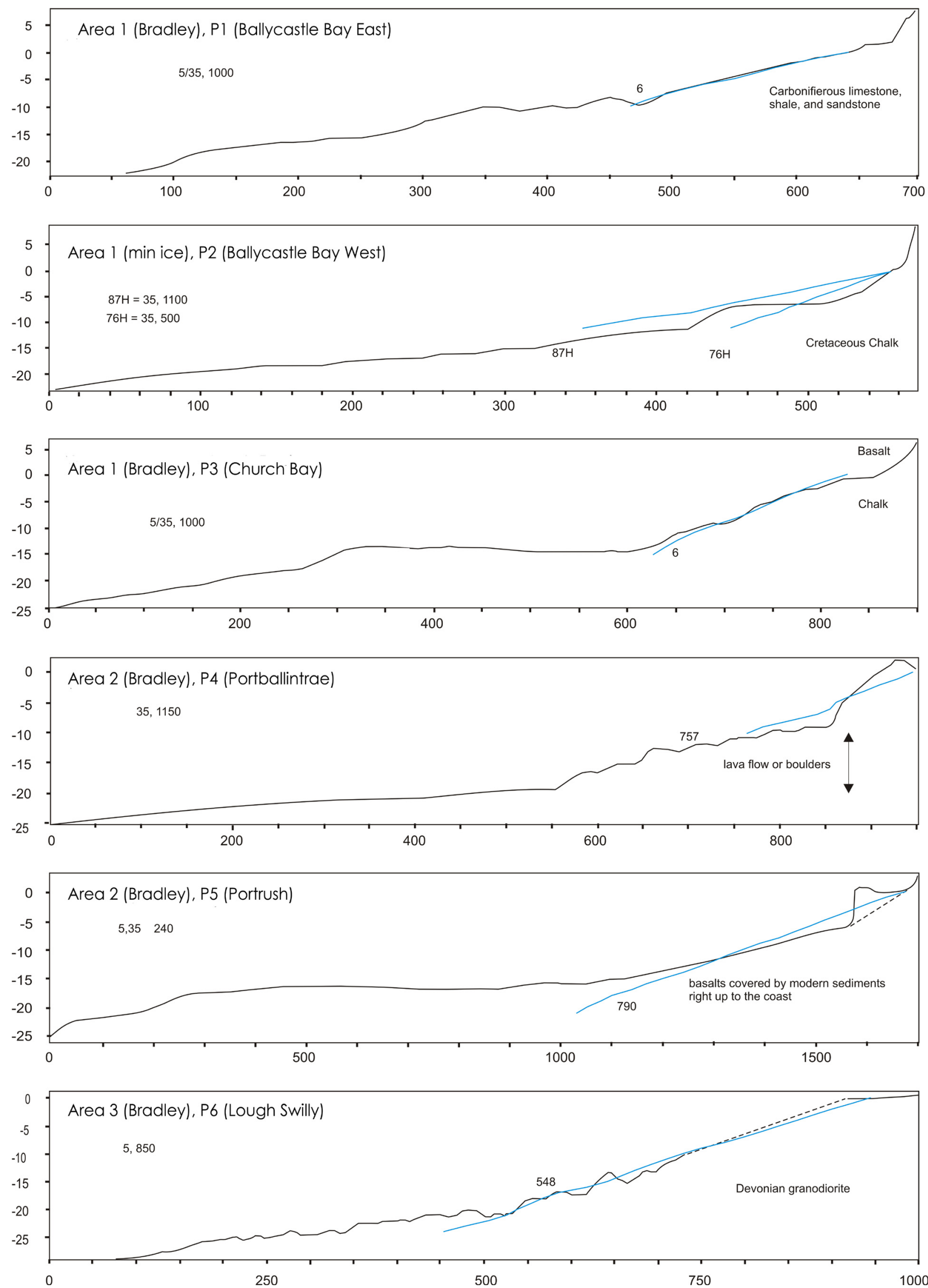

Figure 8: Simulated mean profile gradients (blue lines) plotted against the measured composite profiles for each of the study areas (black lines). Figures refer to the initial profile gradients (linear 50 slope or composite 50 slope with a 35 - inherited cliff) and the rock resistance (SFcr) used in each run. For clarity, the simulated profiles are only plotted for the height range over which modification of the initial surface occurred. These best-fit profiles are produced by the relative sea-level curves generated from the Bradley model (Bradley et al., 2011) with the exception of Profile 2 which is derived from the Hub-min scenario (Kuchar et al., 2012). 
information. The simulations performed here permit a first order assessment of the extent and distribution of potentially inherited features to be made.

Whilst the bathymetric data contain abundant evidence for submerged sub-horizontal platforms at a range of depths, the model simulations fail to reproduce similarly sized features anywhere within the subtidal zone. Whilst platforms can be created at lowstands by lowering the resistive strength of the rock, these are then removed by subsequent RSL rise. In more resistant rocks, the duration of lowstands is insufficient to create features of comparable scale. Hence, to form and subsequently preserve these features, RSL is required to occupy lower elevations for more extended periods of time than in any of our simulations. By definition, any feature below the minima of the simulated RSL curves (c. $-12 m,-15 m$ and $-25 m$ for Areas 1,2 and 3 respectively) predates $16,000 \mathrm{BP}$.

Similarly, whilst raised terrace features are produced in some of the model runs with a steep inherited cliff etched in resistant rock, no single RSL curve or combination of parameters replicates the terrestrial shoreline features reported from this region. The most pronounced raised features are generated in runs driven by the Hub-min and Hub-max RSL models, since these have intervals of quasi-stable higher than present RSL associated with Meltwater pulse 1a. Cliff-line retreat precludes the preservation of raised shoreline features in scenarios with low rock resistive strength. Whilst detailed comparison between simulated terraces and recorded 'raised shorelines' is premature, simulated terrace heights show broad agreement with the elevations of some inferred postglacial shorelines. For example, modelled terraces are found between +8 and +14 $\mathrm{m}$ in Areas 1 and 2, compared to a general upper limit of postglacial raised shorelines across the region of between c. +7 to $+13 \mathrm{~m}$. More detailed field mapping to separate composite shoreline features, coupled with improved constraints on model parameters is required before more specific comparisons can be made.

Since consideration of the overall mean profile gradients indicates shorelines are cut into resistant rock with moderate to slow rates of erosion, the formation of numerous platforms or terraces requires RSL to occupy certain height ranges for more extended periods of time than in our simulated RSL curves. Providing the modelled parameters give a reasonable approximation of conditions since deglaciation, these results suggest that some of the raised platforms and most of the submerged platforms are inherited from an earlier phase or phases of RSL.

As with all modelling studies, these interpretations are associated with some caveats relating to parameter / variable choice. Firstly, the models are run using modern hydrographic data. Changes in wind-wave climate through time are likely and may alter the rate of erosion (e.g. Neill et al., 2009, 2010), although to some extent any deviation in erosive power is offset during selection of rock resistance in order to minimise the misfit between modelled and measured mean profile gradients. Similarly, previous numerical modelling indicates that tidal range changes are likely to have occurred since deglaciation (Uehara et al., 2006). Whilst a larger tidal range could potentially alter the height at which simulated shore platforms are formed, it would not induce widespread shore platform formation at the range of elevations apparent in the DEM.

Secondly, whilst rock resistance is varied between runs and simulated profiles, we did not modulate critical surf stresses within an individual profile (to simulate vertical differences in rock strength) or through time. The latter could be significant where recently deglaciated terrains are exposed to extreme freeze-thaw action, initially rendering the surface weaker and more easily eroded (Robinson and Jerwood, 1987; Fournier and Allard, 1992; Trenhaile, 2002). The high levels of saturation and salinity associated with the intertidal, spray and splash zones are certainly conducive to frost weathering (Trenhaile and Mercan, 1984), whilst the action of glacial or drifting ice itself are also potentially significant erosive agents (e.g. Dionne and Brodeur, 1988; Hansom and Kirk, 1989). Conceivably, these combined effects could promote rapid shore platform development immediately following deglaciation, although this will tend to be offset by the comparatively rapid rate of RSL fall associated with the early phase of glacioisostatic rebound. Whilst our study locations were selected to avoid major within-profile lithological changes, more detailed, location specific analyses would benefit from incorporating any known vertical variations in rock resistance revealed by fieldwork, diving or drop-camera surveys. Similarly, previous modelling studies have considered both wave and weathering effects on shore platform genesis (e.g. Trenhaile, 2008, 2010), and inclusion of a time-variable weathering term would also be a useful addition to future work in this region.

Finally, the models are driven by simulated RSL curves which, whilst representing the current state of the art, are comparatively poorly constrained by field data in the study area (especially during the early stages of deglaciation). Modification of the RSL curve to promote lengthier still-stands at certain heights would produce more terrace and shore platform features (e.g. the possible highstand around $+19 \mathrm{~m}$ in McCabe et al., 2007). However, there remains a finite amount of time within which to accommodate RSL change, hence extending the duration of still-stands, or expanding RSL maxima / minima, requires concomitantly more abrupt RSL rises and falls, ultimately producing a step-like RSL curve that is physically implausible.

The height of the simulated cliff-platform junction is particularly sensitive to the choice of RSL curve used to drive the wave-erosion model. In areas experiencing RSL rise during the Holocene, cliff-platform junctions typically occur between mid-tide and spring high tide level, with higher levels corresponding to more resistant rocks (Everard et al., 1964; Wright, 1970; Trenhaile, $1972,1978,2010)$. In the study area, the cliff foot is typically above present high tidal level, consistent with formation during higher than present RSL. The approximate height of the cliffplatform junction determined from the topographic data ranges from between c. $+1.8 \mathrm{~m}$ and $+2.3 \mathrm{~m}$ OD in Antrim (MHWST $=+0.5$ $m$ OD) to between c. $-1.3 \mathrm{~m}$ and $-0.2 \mathrm{~m}$ OD near Lough Swilly (MHWST $=+1.3 \mathrm{~m} \mathrm{OD})($ Table 3$)$. This height trend reflects the 
widely recognised westward tilt in shoreline features resulting from increased isostatic rebound toward the northeast of Ireland. This general geometry is reflected in the simulated RSL curves although, with the exception of the Hub-Min model, the simulated height of the cliff base is over-predicted (Table 3). The sensitivity of cliff base height to differences in simulated RSL suggests that more detailed work compiling field measurement of cliff-platform junction height, lithology and wave climate could provide useful additional constraints on modelled RSL curves.

\section{Conclusions}

Rocky shoreline profiles generated from a wave-erosion model driven by simulated RSL curves for the past 16,000 years, approximate the overall mean gradients of most measured shoreline profiles in the study area. In these profiles, breaks in mean slope are observed at depths comparable to the RSL minima in several of the RSL scenarios, with shallower depths being erosively modified since deglaciation. All RSL scenarios replicate the observed geometry of changes in cliff-platform junction height along the coast, although several overestimate the actual elevations inferred from the topographic data. Whilst some of the RSL scenarios produce a limited number of raised shore platforms at comparable heights to similar features reported in the literature, no single curve or combination of parameters is capable of generating the range of platform and terrace features present in the bathymetric and topographic data. This is consistent with the idea that many of these features are inherited from an earlier phase or phases of RSL.

The combination of wave, weathering and glacial rebound models has the potential to provide new insights into the extent to which shore platforms are of contemporaneous or polygenetic origin. The objective of the present study was to provide a broad, first assessment of rocky shoreline profile development at the regional scale which may serve as a framework for future investigations. More detailed work, targeting particular shoreline features is now required, and this must be underpinned by improved field data regarding wave and rock characteristics as well as the morphology of rock platforms and their relationship to other 'shoreline' features.

\section{Acknowledgements}

This material is based upon work supported by the Science Foundation Ireland under Grant No. 09/RFP/GEO2393 (Edwards / Thébaudeau), and through Discovery Grants from the Natural Sciences and Engineering Research Council of Canada (Trenhaile). Many thanks to Ruth Plets, Rory Quinn and Kieran Westley (University of Ulster) for supplying processed bathymetric data from the Joint Irish Bathymetric Survey (JIBS) Project, and photographs of the field area (Fig. 2). The JIBS Project (EU INTERREG IIIA Programme) was co-ordinated by the Department of the Environment for Northern Ireland and led by the Maritime and Coastguard Agency in partnership with the Marine Institute of Ireland. We are grateful to Joseph Kuchar and Alun Hubbard for supplying two of the simulated relative sea-level curves (Hub-Min and Hub-Max) used in this research.
Topographic, LIDAR and wave data were supplied by the Ordnance Survey Ireland, Ordnance Survey of Northern Ireland and the Marine Institute. We are grateful to Jim Hansom, David Smith and an anonymous reviewer for their comments on the manuscript.

\section{REFERENCES}

Blanco Chao, R., Costa Casais, M., Martínez Cortizas, A., Pérez Alberti, A., Trenhaile, A.S., 2003. Evolution and inheritance of a cock coast: western Galicia, northwestern Spain. Earth Surface Processes and Landforms 28, 757-775.

Bradley, S., Milne, G., Shennan, I., Edwards, R.J., 2011. An improved glacial isostatic adjustment model for the British Isles. Journal of Quaternary Science 26, 541-552.

British Admiralty Tide Tables 20-11. United Kingdom and Ireland (np 201-11, vol. 1). UK Hydrographic Office, Taunton, Somerset.

Brooke, B.P., Young, R.W., Bryant, E.A., Murray-Wallace, C.B., Price, D.M., 1994. A Pleistocene origin for shore platforms along the northern Illawarra coast, New South Wales. Australian Geographer 25, 178-185.

Brooks, A., Edwards, R., 2006. The development of a sea-level database for Ireland. Irish Journal of Earth Sciences 24, 13-27.

Brooks, A.J., Bradley, S.L., Edwards, R.J., Milne, G.A., Horton, B., Shennan, I., 2008. Postglacial relative sea-level observations from Ireland and their role in glacial rebound modelling. Journal of Quaternary Science 23, 175-192.

Carter, R.W.G., 1982. Sea-level changes in Northern Ireland. Proceedings of the Geologists' Association 93, 7-23.

Carter, R.W.G., 1983. Raised coastal landforms as products of modern process variations, and their relevance in eustatic sea-level studies: example from eastern Ireland. Boreas 12, 167-182.

Clark, C.D., Hughes, A.L.C., Greenwood, S.L., Jordan, C., Sejrup, H.P., 2012. Pattern and timing of retreat of the last British-Irish Ice Sheet. Quaternary Science Reviews 44, 112-146.

Coffey, G., Praeger, R.L., 1904. The Antrim raised beach: a contribution to the Neolithic history of the North of Ireland. Proc. Roy. Ir. Acad. 6, 143-200.

Cooper, J.A.G., Kelley, J.T., Belknap, D.F., Quinn, R., McKenna, J., 2002. Inner shelf seismic stratigraphy off the north coast of Northern Ireland; new data on the depth of the Holocene lowstand. Marine Geology 186, 369-387.

Devoy, R.J., 1983. Late Quaternary shorelines in Ireland: an assessment of their implications for isostatic land movement and relative sea-level changes. In: Smith, D., Dawson, A.G. (Eds.), Shorelines and Isostasy. Academic Press, London, pp. 227-254.

Devoy, R.J.N., 1995. Deglaciation, earth crustal behaviour and sea-level changes in the determination of insularity: a perspective from Ireland. In: Preece, R.C. (Ed.), Island Britain: a Quaternary perspective. Geological Society (London) Special Publication 96, pp. 209-242.

Dionne, J.C., Brodeur, D., 1988. Frost weathering and ice action in shore platform development with particular reference to Quebec, Canada. Zeitschrift für Geomorphologie, Supplementband 71, 117-130.

Dunlop, P., Shannon, R., Mccabe, M., Quinn, R., Doyle, E., 2010. Marine geophysical evidence for ice sheet extension and recession on the Malin Shelf: New evidence for the western limits of the British Irish Ice Sheet. Marine Geology 276, 86-99.

Edwards, R., Brooks, A., Shennan, I., Milne, G., Bradley, S., 2008. Reply: Postglacial relative sea-level observations from Ireland and their role in glacial rebound modelling. Journal of Quaternary Science 23, 821-825.

Everard, C.E., Lawrence, R.H., Witherick, M.E., Wright, L.W., 1964. Raised beaches and marine geomorphology. In: Hosking, K.F.G., Shrimpton, G.J. (Eds.), Present views on some aspects of the Geology of Cornwall and Devon. Royal Geological Society of Cornwall, Penzance, pp. 283-310. 
Fournier, A., Allard, M., 1992. Periglacial shoreline erosion of a rocky coast: George River Estuary, northern Quebec. Journal of Coastal Research 8, 926942.

Hansom, J.D., Kirk, R.M., 1989. Ice in the intertidal zone: examples from Antarctica. In: Bird, E.C.F., Kelletat, D. (Eds.), Zonality of Coastal Geomorphology and Ecology. Essener Geographische Arbeiten 18, pp. 211-236.

Kelley, J.T., Cooper, J.A.G., Jackson, D.W.T., Belknap, D.F., Quinn, R.J., 2006. Sealevel change and inner shelf stratigraphy off Northern Ireland. Marine Geology 232, 1-15.

Kuchar, J., Milne, G., Hubbard, A., Patton, H., Bradley, S., Shennan, I., Edwards, R., 2012. Evaluation of a numerical model of the British - Irish ice sheet using relative sea - level data: implications for the interpretation of trim line observations. Journal of Quaternary Science 27, 597-605.

Lambeck, K., 1995. Late Devensian and Holocene shorelines of the British Isles and North Sea from models of glacio-hydro-isostatic rebound. Journal of the Geological Society 152, 437-448.

Lambeck, K., Purcell, A.P., 2001. Sea-level change in the Irish Sea since the last glacial maximum; constraints from isostatic modelling. Journal of Quaternary Science 16, 497-506.

McCabe, A., 2008. Comment: Postglacial relative sea-level observations from Ireland and their role in glacial rebound modelling. Journal of Quaternary Science 23, 817-820.

McCabe, A.M., Dunlop, P., 2006. The Last Glacial Termination in Northern Ireland. Geological Survey of Northern Ireland, Belfast, 93pp.

McCabe, A.M., Cooper, J.A.G., Kelley, J.T., 2007. Relative sea-level changes from NE Ireland during the last glacial termination. Journal of the Geological Society 164, 1059-1063.

McCann, N., 1988. An Assessment of the Subsurface Geology between Magilligan Point and Fair Head, Northern Ireland. Irish Journal of Earth Sciences 9, 71-78.

McKenna, J., 2002. Basalt cliffs and shore platforms between Portstewart (Co. Derry) and Portballintrae (Co. Antrim). In: Knight, J. (Ed.), Field Guide to the Coastal Environments of Northern Ireland. International Coastal Symposium (ICS), University of Ulster, Coleraine, Northern Ireland, pp. 157-164.

McKenna, J., 2008. Quaternary raised shorelines on the north coast of Ireland. In: Whitehouse, N.J., Roe, H., McCarron, S., Knight, J. (Eds), North of Ireland: Field Guide. Quaternary Research Association, London, pp. 208-215.

McKenna, J., Carter, R.W.G., Bartlett, D., 1992. Coast erosion in northeast Ireland:-Part II Cliffs and shore platforms. Irish Geography 25, 111-128.

Movius, H.L., 1953. Graphic representation of post-glacial changes of sea level in north-east Ireland. Am. J. Sci. 251, 697-740.

Naylor, L.A., Stephenson, W.J., Trenhaile, A.S., 2010. Rock coast geomorphology: Recent advances and future research directions. Geomorphology 114, 3-11.

Neill, S.P., Scourse, J.D., Bigg, G.R., Uehara, K., 2009. Changes in wave climate over the northwest European shelf seas during the last 12,000 years. Journal of Geophysical Research 114, C06015.

Neill, S.P., Scourse, J.D., Uehara, K., 2010. Evolution of bed shear stress distribution over the northwest European shelf seas during the last 12,000 years. Ocean Dynamics 60, 1139-1156.

Nicholls, R.J., Wong, P.P., Burkett, V., Codignotto, J., Hay, J., McLean, R., Ragoonaden, S., Woodroffe, C.D., 2007. Coastal systems and low-lying areas. In: Parry, M.L., Canziani, O.F., Palutikof, J.P., Van der Linden, P., Hanson, C.E. (Eds), Climate Change 2007: Impacts, Adaptation and Vulnerability. Contribution of Working Group II to the Fourth Assessment Report of the Intergovernmental Panel on Climate Change. Cambridge University Press, Cambridge, pp. 315357.

Orme, A.R., 1966. Quaternary Changes of Sea-level in Ireland. Transactions of the Institute of British Geographers 39, 127-140.
Orford, J.D., Betts, N.L., Cooper, J.A.G., Smith, B.J., 2007. Future coastal scenarios for Northern Ireland. Report for the National Trust (NI), Belfast, 178 pp.

Peltier, W.R., Shennan, I., Drummond, R., Horton, B., 2002. On the postglacial isostatic adjustments of the British Isles and the shallow viscoelastic structure of the Earth. Geophysical Journal International 148, 443-475.

Praeger, R.L., 1897. Report on the raised beaches of the north-east of Ireland. Proc. R. Ir. Acad. 4, 30-54.

Prior, D.B., 1965. Late glacial and post-glacial shorelines in north-east Antrim. Irish Geography 5, 173-187.

Quinn, R., Plets, R., Clements, A., Westley, K., Forsythe, W., Bell, T., Robinson, R., Benetti, S., 2010. Phase 3 of Archaeological applications of the Joint Irish Bathymetric Survey (JIBS) data. Final Report submitted to the Heritage Council, pp. 162.

Robinson, D.A., Jerwood, L.C., 1987. Subaerial weathering of chalk shore platforms during harsh winters in southeast England. Marine Geology 77, 114.

Shennan, I., Bradley, S., Milne, G., Brooks, A., Bassett, S., Hamilton, S., 2006. Relative sea-level changes, glacial isostatic modelling and ice-sheet reconstructions from the British Isles since the last glacial maximum. Journal of Quaternary Science 21, 585-599.

Smart, C.C., Hale, P.B., 1987. Exposure and inundation statistics from published tide tables. Computer Geoscience 13, 357-368.

Stephens, N., 1963. Late-glacial sea levels in north-east Ireland. Ir. Geogr. 4, 345-359.

Stephenson, W.J., Naylor, L.A., 2011. Geological controls on boulder production in a rock coast setting: Insights from South Wales, UK. Marine Geology 283, 12 24.

Stone, J., Lambeck, K., Fifield, L.K., Evans, J.M., Cresswell, R.G., 1996. A Lateglacial age for the Main Rock Platform, western Scotland. Geology 24, 707710.

Swantesson, J.O.H., Gómez-Pujol, L., Cruslock, E.M., Fornoós, J.J., Balaguer, P., 2006. Processes and patterns of erosion and downwearing on micro-tidal rock coasts in Sweden and the western Mediterranean. European Shore Platform Dynamics. Zeitschrift für Geomorphologie, Supplement Band 144, 137-160.

Synge, F.M., Stephens, N., 1966. Late- and Post-Glacial Shorelines, and Ice Limits in Argyll and North-East Ulster. Transactions of the Institute of British Geographers 39, 101-125.

Trenhaile, A.S., 1972. The shore platforms of the Vale of Glamorgan, Wales. Transactions of the institute of British Geographers 56, 127-144.

Trenhaile, A.S., 1978. The shore platforms of Gaspé, Québec. Annals of the Association of American Geographers 68, 95-114.

Trenhaile, A.S., 1987. The Geomorphology of Rock Coasts. Oxford University Press, Oxford.

Trenhaile, A.S., 1997. Coastal Dynamics and Landforms. Oxford University Press, Oxford

Trenhaile, A.S., 2000. Modeling the development of wave-cut shore platforms. Marine Geology 166, 163-178.

Trenhaile, A.S., 2001. Modeling the Quaternary evolution of shore platforms and erosional continental shelves. Earth Surface Processes and Landforms 26, 1103-1128.

Trenhaile, A.S., 2002. Modeling the development of marine terraces on tectonically mobile rock coasts. Marine Geology 185, 341-361.

Trenhaile, A.S., 2008. Modeling the role of weathering in shore platform development. Geomorphology 94, 24-39.

Trenhaile, A.S., 2010. The effect of Holocene changes in relative sea level on the morphology of rocky coasts. Geomorphology 114, 30-41. 
Trenhaile, A.S., 2012. Cliffs and Rock Coasts. In: Hansom, J.D., Flemming, B.W. (Eds.), Estuarine and coastal geology and geomorphology. Volume 3 of Treatise on Estuarine and Coastal Science. Elsevier, Amsterdam, pp. 171-191.

Trenhaile, A.S., Mercan, D.W., 1984. Frost weathering and the saturation of coastal rocks. Earth Surface Processes and Landforms 9, 321-331.

Trenhaile, A.S., Byrne, M.L., 1986. A theoretical investigation of rock coasts, with particular reference to shore platforms. Geogr. Ann. 68A, 1-14.

Trenhaile, A.S., Kanyaya, J.I., 2007. The role of wave erosion on sloping and horizontal shore platforms in macro- and mesotidal environments. Journal of Coastal Research 23, 298-309.

Trenhaile, A.S., Pérez Alberti, A., Martínez Cortizas, A., Costa Casais, M., Blanco Chao, R., 1999. Rock coast inheritance: an example from Galicia, northwestern Spain. Earth Surface Processes and Landforms 24, 605-621.

Uehara, K., Scourse, J.D., Horsburgh, K.J., Lambeck, K., Purcell, A.P., 2006. Tidal evolution of the northwest European shelf seas from the Last Glacial Maximum to the present. J. Geophys. Res. 111, C09025.

Wright, L.W., 1970. Variation in the level of the cliff/shore platform junction along the south coast of Great Britain. Marine Geology 9, 347-353.

Young, R.W., Bryant, E.A., 1993. Coastal rock platforms and ramps of Pleistocene and Tertiary age in southern New South Wales, Australia. Zeitschrift für Geomorphologie 37, 257-272. 